\title{
Influence of the Position of Mango Fruit on the Tree (Mangifera indica L. CV. 'Zibda') on Chilling Sensitivity and Antioxidant Enzyme Activity
}

\author{
A. A. Lo'ay ${ }^{1, *(D)}$, Nada A. Mostafa ${ }^{2}\left(\mathbb{D}\right.$, Salem Mesfir Al-Qahtani ${ }^{3}\left(\mathbb{D}\right.$, Nadi Awad Al-Harbi $^{3}\left(\mathbb{D}\right.$, Sabry Hassan $^{4}(\mathbb{D}$ and \\ Mohamed A. Abdein 5 (D) \\ 1 Pomology Department, Faculty of Agriculture, Mansoura University, El-Mansoura 35516, Egypt \\ 2 Botany Department, Faculty of Agriculture, Mansoura University, El-Mansoura 35516, Egypt; \\ nadaalmoazen@mans.edu.eg \\ 3 Biology Department, University College of Tayma, Tabuk University, Tabuk 71411, Saudi Arabia; \\ salghtani@ut.edu.sa (S.M.A.-Q.); nalharbi@ut.edu.sa (N.A.A.-H.) \\ 4 Department of Biology, College of Science, Taif University, Taif 21944, Saudi Arabia; hassan@tu.edu.sa \\ 5 Department of Biology, Faculty of Arts and Science, Northern Border University, Rafha 91911, Saudi Arabia; \\ abdeingene@yahoo.com \\ * Correspondence: Loay_Arafat@mans.edu.eg
}

\section{check for}

updates

Citation: Lo'ay, A.A.; Mostafa, N.A.; Al-Qahtani, S.M.; Al-Harbi, N.A.;

Hassan, S.; Abdein, M.A. Influence of the Position of Mango Fruit on the Tree (Mangifera indica L. CV. 'Zibda') on Chilling Sensitivity and Antioxidant Enzyme Activity. Horticulturae 2021, 7, 515. https:// doi.org/10.3390/horticulturae7120515

Academic Editors: Pai-Tsang Chang, Wen-Ju Yang and Jer-Chia Chang

Received: 27 September 2021

Accepted: 30 October 2021

Published: 23 November 2021

Publisher's Note: MDPI stays neutral with regard to jurisdictional claims in published maps and institutional affiliations.

Copyright: (c) 2021 by the authors. Licensee MDPI, Basel, Switzerland. This article is an open access article distributed under the terms and conditions of the Creative Commons Attribution (CC BY) license (https:// creativecommons.org/licenses/by/ $4.0 /)$.
Abstract: Mango fruits sourced from tropical yields have had a high commercial comeback from being viewed as susceptible to chilling injury under long storage durations. When the fruits are exposed to cold storage, this results in physiological changes due to the side effects of the storage on the fruits, expanding the rates of loss during the period between harvest and marketing. It is difficult to harvest mangoes as the fruits show varying maturities and are located in different positions on the trees. The purpose of this study was to test the idea that fruits' location on the tree influences how the fruit behaves during cold storage. During two seasons (2019-2020), the impact of on-tree fruit location, i.e., sunny side (SUN; fruit exposed to the sun for most of the day), shade (SHA; fruit grown on the shady side of trees), and inside the canopy (INS; fruit grown inside the tree canopy), on the chilling sensitivity and the activities of antioxidant enzymes of 'Zibda' mangos stored at a low temperature $\left(4 \pm 1^{\circ} \mathrm{C}\right)$ for 35 days was determined. In contrast to SHA and SUN mangos, INS fruits were shown to be progressively tolerant to low storage temperatures. These fruits also showed the highest activities of ascorbate peroxidase (APX), peroxidase (POD), catalase (CAT), and superoxide dismutase (SOD). In addition, the contents of $\mathrm{O}_{2}{ }^{-}$and $\mathrm{H}_{2} \mathrm{O}_{2}$ decreased in INS fruit during storage. Consequently, the cell membrane compartments were maintained, showing low accumulation of both malondialdehyde (MDA) and the protein carbonyl group (PCG) during storage. These results indicate that the fruit positions can also be considered at the time of harvesting for the classification of fruits before cold storage. This classification can also be added to the mango trading protocol to minimize the loss of economic returns by chilling injury.

Keywords: fruit location; mango; cold storage; chilling injury

\section{Introduction}

Mango is a natural product and is cultivated in numerous regions of the world, for example, Latin America (Brazil, Chile, Venezuela), Africa (Egypt and South Africa) and Asia (Philippines, Malaysia, India) [1]. Further, mango is a favorite natural fruit for consumers and a source of great economic income, which is exported to numerous regions of the world. Lately, the advancement of the mango worldwide exchange markets is because of the numerous mango varieties that have spread everywhere throughout the world as of late [2]. Mango was planted in Egypt throughout the rule of the Muhammad Ali Pasha period since 1825. The total harvested area of mango in Egypt is about 135,524 hectares 
(harvested area) producing 1,473,538 tons [3]. Mangoes are also classified as tropical fruits, which mature or deteriorate very quickly after harvesting or during frequent trading [4].

Producers have focused on mitigating losses in yield. However, few investigations have discussed the variations in the postharvest quality of fruits or vegetables connected to climate change (temperature changes). Recent influences and effects on sustainable development have gained attention [5]. Further, rising temperatures increase the saturation of the air with water vapor. Increased water evaporation from fruit also leads to reduced yields and rapid ripening of fruits [6]. Additionally, high temperatures lead to many natural, anatomical, physiological, and biological variations in fruit tissue [7]. One consequence of exposure to high temperatures for a long time is the accelerated ripening of the fruits of avocado. It also influences the hardness of the fruits in terms of the effect on the activity of cell wall decomposition enzymes, for example, cellulase and polygalacturonase [8]. Another symptom of exposure to high temperatures of more than $40^{\circ} \mathrm{C}$ is that apple fruits exhibited more incidences of sunburn, water core, and more rapid softening [9].

Therefore, the use of low temperatures during storage of mangos reduces fruit losses and biological processes in fruits after harvesting. However, there is a chilling injury phenomenon $(\mathrm{CI})$ of cold temperature on the fruit that limits the use of cold storage in mango trading [10]. Mango fruits are tropical and subtropical fruits that are sensitive to low temperatures of less than $13{ }^{\circ} \mathrm{C}$ [4]. Consequently, an increase in metabolic changes generates $\mathrm{CI}$ in fruits, which occurs by extending the storage period, leading to a significant change in the cellular walls and membranes [11], as well as minimizing ethylene gas production and the respiratory rate [12]. Under long-term storage, CI symptoms appear in the form of a small patch around the lenticels on the surface of the fruit due to the dying cells around them. CI develops afterward to combine to form large black spot areas on the fruit skin [13]. Numerous investigations have confirmed that reactive oxygen species (ROS) are generated from different cell organelles, such as the cytoplasm, cell wall, plasma cell membranes, and mitochondria ( $85 \%$ ROS production), which react indiscriminately with different molecules inside the cell [14]. The common important ROS formed during the storage period of the mango is the hydroxyl radical $\left(\mathrm{OH}^{\bullet}\right)$ and singlet oxygen $\left({ }^{1} \mathrm{O}_{2}\right)$ [15]. Both radicals react, especially in double bonds along the carbon chain of the organic molecules, forming new compounds [16]. Some studies focused on alleviating CI by using organic acids such as oxalic acid at $20 \mathrm{mM}$ [17], or applying methyl jasmonate and methyl salicylate [18], or using low-temperature conditioning during cold storage [19].

The developing fruits on trees are subjected to heat and ultra-violet radiation stress (UV) to varying degrees during the day, which will decrease the activity of antioxidants throughout cold storage. Therefore, our hypothesis is that the difference in the locations (sunny, shaded, and the inside of trees) of the mango fruits affects the behavior of the fruits under cold storage [20].

\section{Materials and Methods}

\subsection{Fruit Materials and Experimental Setup}

Mango fruits of cv. Zibda were harvested in August 2019 and 2020 from trees that were ten years old and planted at $8 \times 10$ meters in the sandy soil of a commercial orchard. Experiments on biological differences were conducted on mango trees grown in Sharkia Province, East Egypt $\left(30.5765^{\circ} \mathrm{N}, 31.5041^{\circ} \mathrm{E}\right)$. According to the Egyptian Meteorological Authority, meteorological observations were taken in terms of average temperatures, the number of daylight hours, and the intensity of incoming radiation in the region (Figures 1-3). 


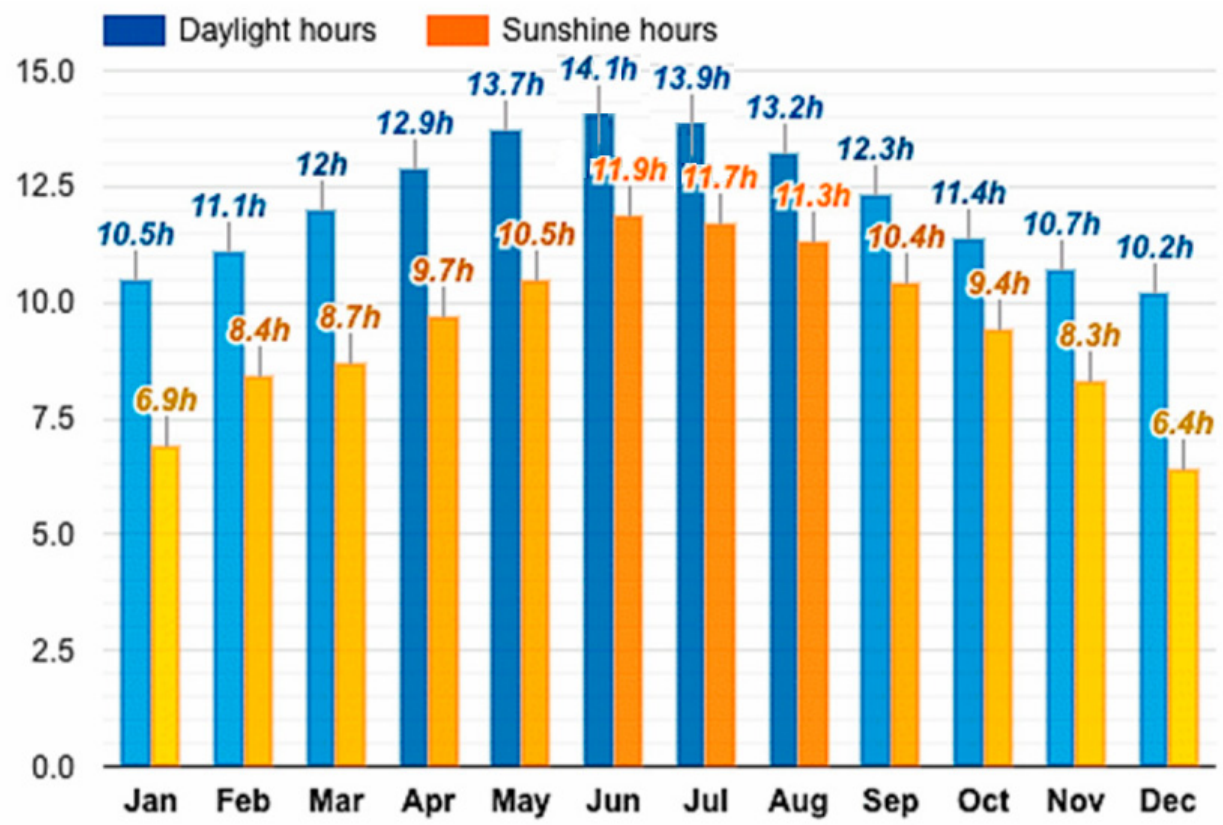

Figure 1. The average daylight and sunshine duration per month during the growth season.

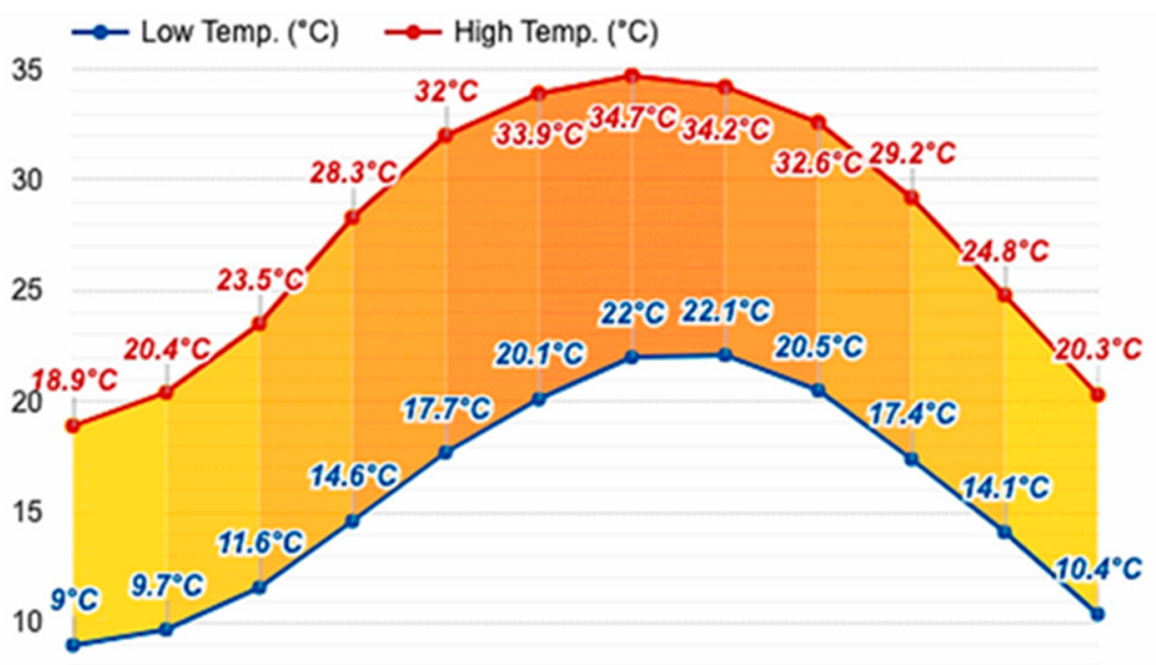

Jan Feb Mar Apr May Jun Jul Aug Sep Oct Nov Dec

Figure 2. The average low and high temperatures per month during the growth season.

The objective of this study is to determine the influence of fruit location on trees and its relationship to the chilling injury symptoms that occur during cold storage stress. The experiment was conducted on 360 fruits on mango trees at three distinct sites: the sunny side (SUN; fruit exposed to the sun for most of the day), shaded (SHA; fruit grown on the shady side of trees), and inside the canopy (INS; fruit grown inside the tree canopy (Figure 4). Fruits were harvested at the half ripe fruit stage (fruits at the shoulder were at the same level as at the stem end) [21]. The fruits were divided into two batches of 180 each. 


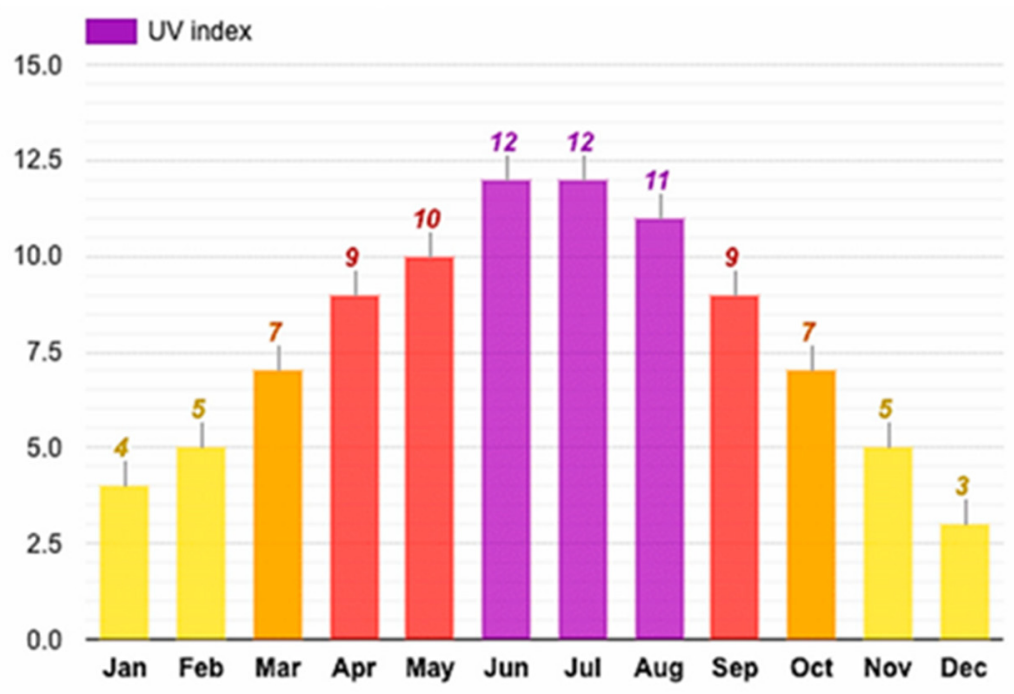

Figure 3. The average UV-index per month during the growth season.

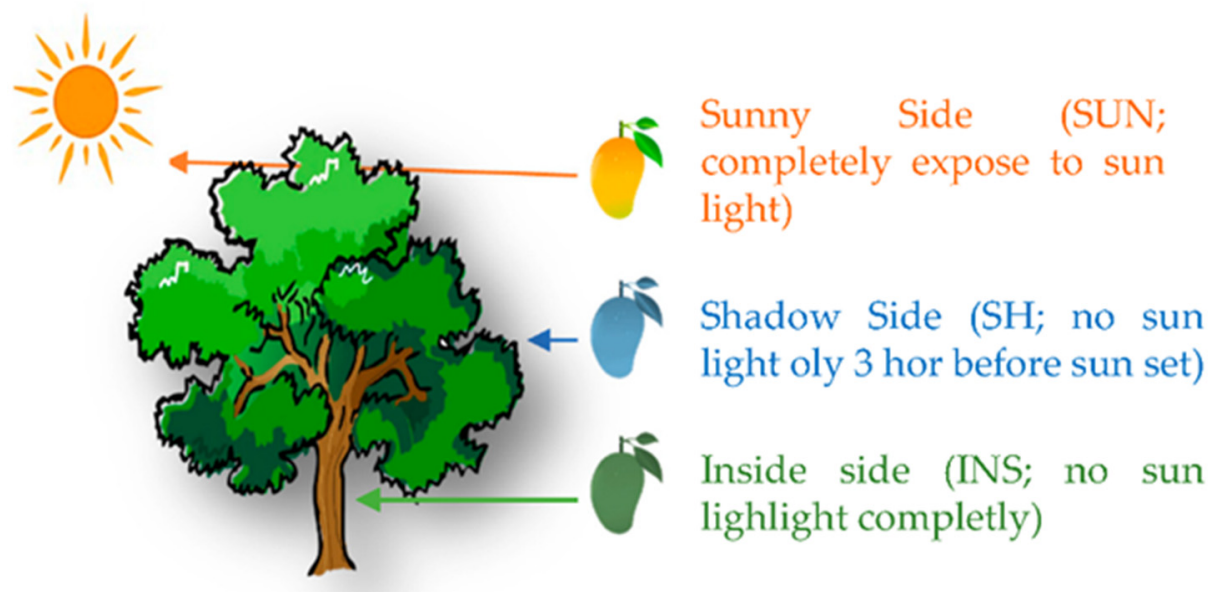

Figure 4. The fruit location on the trees according to exposure to sun rays (environmental stress).

One batch was reserved for non-destructive measures, while the other was reserved for chemical assays. Both batches were replicated three times. Fruits were stored at low temperature for 35 days. The cold storage system was a vapor compression (V-C) refrigeration system in a cold room at $4 \pm 1{ }^{\circ} \mathrm{C}$ with a relative humidity of $96 \pm 2 \%$.

\subsection{Ci-Index and Electrolyte Leakage (El\%)}

External injuries to the fruit peel, such as pitting, water-soaked regions, and rotting, are frequently used to determine the CI [22]. The visual symptom rating scale had the following values: 1 for no injuries, 2 for minor injuries, 3 for moderate injuries, 4 for serious injuries, and 5 for extremely severe injuries. The CI incidence was calculated using Formula (1):

$$
\text { Chilling injury }- \text { Index }=\sum_{1 \rightarrow 5}^{5} \frac{(\text { Chilling injury level }) *(\text { Numer of fruit at this level })}{\text { Total number of fruit }}
$$

The proportion of cell membrane EL\% was determined on five-disc samples (7 mm in diameter) taken from fruit tissues cut at 5-d intervals using a stopper borer from five unique sections of each fruit. Samples were washed three times with demineralized water; the discs were immersed in $10 \mathrm{~mL}$ of $0.4 \mathrm{M}$ mannitol alcohol in demineralized water for $3 \mathrm{~h}$ at $24{ }^{\circ} \mathrm{C}$. [23]. After determination of the electrical conductivity of the water stage with a conductivity meter, the tissue tests were destroyed in a water bath at $100{ }^{\circ} \mathrm{C}$ for $30 \mathrm{~min}$. 
Following that, samples were brought to room temperature to chill before being measured. The conductivity was then tested again to determine the EL percentage. Permeability was calculated using Formula (2):

$$
\mathrm{EL} \%=\frac{\text { Conductivity } \text { after } 3 \mathrm{~h}}{\text { Conductivity } \text { after boiling }}
$$

\subsection{Antioxidant Enzyme Activity Assays}

A fruit sample (10 g) was selected and homogenized with a Kinematical tissue processor (Kinematica AG Werkstrasse $7 \mathrm{c}$-d Switzerland) in $25 \mathrm{~mL}$ of ice-cold extraction buffer and $0.5 \mathrm{~g}$ of polyvinyl-polypyrrolidone (PVPP) (Crl-6010, Kriens-LU, Switzerland). The extraction buffer for the CAT and SOD studies was $50 \mathrm{mM}$ sodium phosphate (pH 7.8). POD was prepared using a $100 \mathrm{mM}$ sodium phosphate cradle ( $\mathrm{pH}$ 6.4). The homogenate mixture was centrifuged at $27,000 \mathrm{~g}$ for $50 \mathrm{~min}$ at $4{ }^{\circ} \mathrm{C}$. The supernatants were then used to determine the activity of CAT and SOD [24].

The reaction combination for CAT analysis consisted of $2.8 \mathrm{~mL} \mathrm{H}_{2} \mathrm{O}_{2}(40 \mathrm{mM}$ in $50 \mathrm{mM}$ sodium phosphate buffer, $\mathrm{pH} 7.0$ ) and $0.2 \mathrm{~mL}$ enzyme extract. The decay of $\mathrm{H}_{2} \mathrm{O}_{2}$ (substrate) was determined by the decrease in absorbance at $240 \mathrm{~nm}$ during a 120-s period using a spectrophotometer (Model UH4150AD UV-Vis-NIR Spectrophotometer Hitachi, Ltd., Tokyo, Japan). The activity was expressed as unit $\mathrm{g}^{-1} \mathrm{FW}$, where one unit of catalase equals one molecule of $\mathrm{H}_{2} \mathrm{O}_{2}$ per mass of fruit per minute at $30{ }^{\circ} \mathrm{C}$.

For the SOD activity assay, a volume of approximately $3 \mathrm{~mL}$ in the SOD activity experiment comprised $65 \mathrm{mM}$ sodium phosphate cradle (pH 7.8). Finally, $13 \mathrm{mM}$ methionine, $75 \mathrm{mM}$ nitro-blue tetrazolium (NBT), $10 \mathrm{mM}$ EDTA, and $2 \mathrm{mM}$ riboflavin were mixed, along with $0.1 \mathrm{~mL}$ of the enzyme extract. After illumination of the combinations for 10 minutes with light $\left(60 \mathrm{Mol} \mathrm{m}^{-2} \mathrm{~s}^{-1}\right)$, the absorbance at $560 \mathrm{~nm}$ was evaluated using a spectrophotometer (Model UH4150AD UV-Vis-NIR Spectrophotometer Hitachi, Ltd., Tokyo, Japan). It took $3 \mathrm{~min}$ for the reaction solution to settle. The reaction was denoted by the unit $\mathrm{g}^{-1} \mathrm{FW}$, where one unit equaled the quantity of chemical that resulted in a $50 \%$ decrease in the SOD inhibitable NBT per mass per hour. The ascorbate peroxidase (APX) reaction was performed on fruit samples [25]. One unit of APX activity was defined as the amount of ascorbate that could be oxidized per minute at $30{ }^{\circ} \mathrm{C}$ by a catalyst; unit $\mathrm{g}^{-1} \mathrm{FW}$ was selected as the change in enzyme activity.

The POD activity was determined, and the increase in absorbance at 398 and $460 \mathrm{~nm}$ was monitored at $30^{\circ} \mathrm{C}$. The POD activity was expressed in units $\mathrm{g}^{-1}$, with one unit representing an enhanced rate of absorbency per mass of fruit samples per minute [26].

\subsection{MDA and PCG Contents}

Malondialdehyde (MDA) is a termination product of lipid peroxidation; $2.5 \mathrm{~g}$ of mango fruit was precisely weighed for MDA extraction [27]. Calibration curves were created and measured using 1,3,3 tetraethyoxypropane (Sigma) with concentrations ranging from 0 to $2 \mathrm{mM}$ (TBARS), which are comparable to 0 to $1 \mathrm{mM}$ MDA. During the acid-heating stop of the test, tetraethyoxypropane was stoichiometrically transformed to MDA.

The protein carbonyl group (PCG) assay was used to determine the endpoint of protein oxidation [28]; $2.5 \mathrm{~g}$ of mango samples was accurately weighed. Spectrophotometric (Model UH4150AD UV-Vis-NIR Spectrophotometer Hitachi, Ltd., Tokyo, Japan) analysis was used to compare the spectra of cured (without sample) samples for a complementary blank or water in the case of pure proteins. The protein carbonyl group (PCG) was assessed by using the absorbance of dinitrophenylhydrazone reagent at $390 \mathrm{~nm}$ and an extinction value of $22,000 \mathrm{M}^{-1} \mathrm{~cm}^{-1}$.

\section{5. $\mathrm{O}_{2}^{-}$and $\mathrm{H}_{2} \mathrm{O}_{2}$ Production Rates}

Fruit samples $(1.0 \mathrm{~g})$ were combined with $3 \mathrm{~mL}$ of cold $50 \mathrm{mM} \mathrm{K}_{3} \mathrm{PO}_{4}$ buffer $(\mathrm{pH} 7.8)$ containing $1 \%(w / v)$ polyvinylpyrrolidone $(\mathrm{PVP})$, followed by centrifugation (Eppendorf 
Model 5702 Georgia, USA) at $8000 \mathrm{~g}$ for $20 \mathrm{~min}$ at $4{ }^{\circ} \mathrm{C}$. The rate of $\mathrm{O}_{2}{ }^{-}$generation was determined by monitoring the formation of nitrite from hydroxylamine in the presence of $\mathrm{O}_{2}{ }^{-}$[29]. The rate of $\mathrm{O}_{2}{ }^{-}$formation from the reaction condition of $\mathrm{O}_{2}{ }^{-}$with hydroxylamine was calculated using a standard curve containing $\mathrm{NO}_{2}$. The rate of $\mathrm{O}_{2}{ }^{-}$formation was expressed as nmol $\mathrm{min}^{-1} \mathrm{~g}^{-1} \mathrm{FW}$.

The assay for $\mathrm{H}_{2} \mathrm{O}_{2}$ used fruit samples $(1.0 \mathrm{~g})$ that were added to $6 \mathrm{~mL}$ of 100 percent $\mathrm{C}_{3} \mathrm{H}_{6} \mathrm{O}$ and centrifuged (Eppendorf Model 5702 Georgia, USA) for $20 \mathrm{~min}$ at $4{ }^{\circ} \mathrm{C}$ at $8000 \mathrm{~g}$. The separated supernatant $(1 \mathrm{~mL})$ was combined with $0.1 \mathrm{~mL}$ of $5 \% \mathrm{Ti}\left(\mathrm{SO}_{4}\right)_{2}$ and $0.2 \mathrm{~mL}$ of a concentrated $\mathrm{NH}_{4} \mathrm{OH}$ solution. The titanium-peroxide complex interacted with the residue added to $4 \mathrm{~mL}$ of $2 \mathrm{M} \mathrm{H}_{2} \mathrm{SO}_{4}$ following a 10-min centrifugation at $8000 \mathrm{~g}$. The $\mathrm{H}_{2} \mathrm{O}_{2}$ concentration was determined at $230 \mathrm{~nm}$ based on a blank solution containing sample extracts without hydrogen peroxide using a standard curve and is expressed as nmol $\mathrm{g}^{-1}$ FW [30].

The DPPH${ }^{\bullet}$ scavenger assay was conducted based on the inhibitor activity of a berry pulp sample, and the dismutation of radical activity technique was enforced. The scavenging outcomes of flavedo samples of DPPH radicals were expressed as a percentage. A $2 \mathrm{~mL}$ sample extraction (with methanol) was combined with $2 \mathrm{~mL}$ of $0.16 \mathrm{mM} \mathrm{DPPH}$ methanolic solvent. Afterward, samples were shaken for one min and kept at room temperature for $30 \mathrm{~min}$ under dark conditions. Consequently, samples were evaluated on a photometer $(517 \mathrm{~nm})$. The value of the DPPH radical was assumed by applying a previously published formula [31].

\subsection{Ethylene and Respiration}

Ethylene and mango respiration were determined at five-day intervals on five mangoes. For all experimental treatments, fruits were sealed in $1000 \mathrm{~mL}$ glass jars with a one-hour gap between each interval of cold storage for days. Gas chromatography techniques were used to extract gas samples from the headspace atmosphere surrounding the fruit and analyze them for ethylene and carbon dioxide (GC). Ethylene concentrations were determined using a GC-6000 Vega Series from Carlo Erba Ins., Italy, while $\mathrm{CO}_{2}$ concentrations were determined using a GC PBI-Dansensor Checkmate-9900 from Denmark.

\subsection{Statistical Analysis}

The two main seasons of data were used for analysis. The experiment was designed as a randomized complete block, and data were analyzed using two-way ANOVA with two factors: fruit location (three levels) and cold storage duration in days (eight levels) with three replicates per treatment. However, data were analyzed as a randomized complete block with one-way ANOVA when the fruit location was a factor (measurements were the same). However, the rest of the measurements were analyzed using a factorial design when the fruit location and cold storage duration were factors. Pearson's correlation matrix and principal component analysis (PCA) were used to determine the relationships between the analyzed parameters. Means separations were done with Tukey's honestly significant difference test $(p \leq 0.05)$. Tukey's HSD test was performed using JMP Pro 16 software, with $p \leq 0.05$ taken as statistically significant (SAS Institute, Cary, NC, USA).

\section{Results}

\subsection{Chilling Injury Symptoms}

The chilling injury symptoms index, as a function of the cold storage period in days for all the fruit locations, is shown in Figure 5. The CI index indicated a significant impact at $p<0.05$ when fruit locations on trees were considered. The fruits were harvested from inside trees (INS), which were more resistant to damage from low-temperature stress compared to other fruit locations. At the storage temperature of $4{ }^{\circ} \mathrm{C}$, there was a clear $\mathrm{CI}$ indication on the 10th day of storage for all fruit locations. The first sign of CI developed on the 10th day for SUN fruit (1.91 CI index, slight injury), on the 15th day for SHA fruit (1.15 CI index, low injury), and on the 20th day for INS fruit (1.03 CI index, trace injury). 


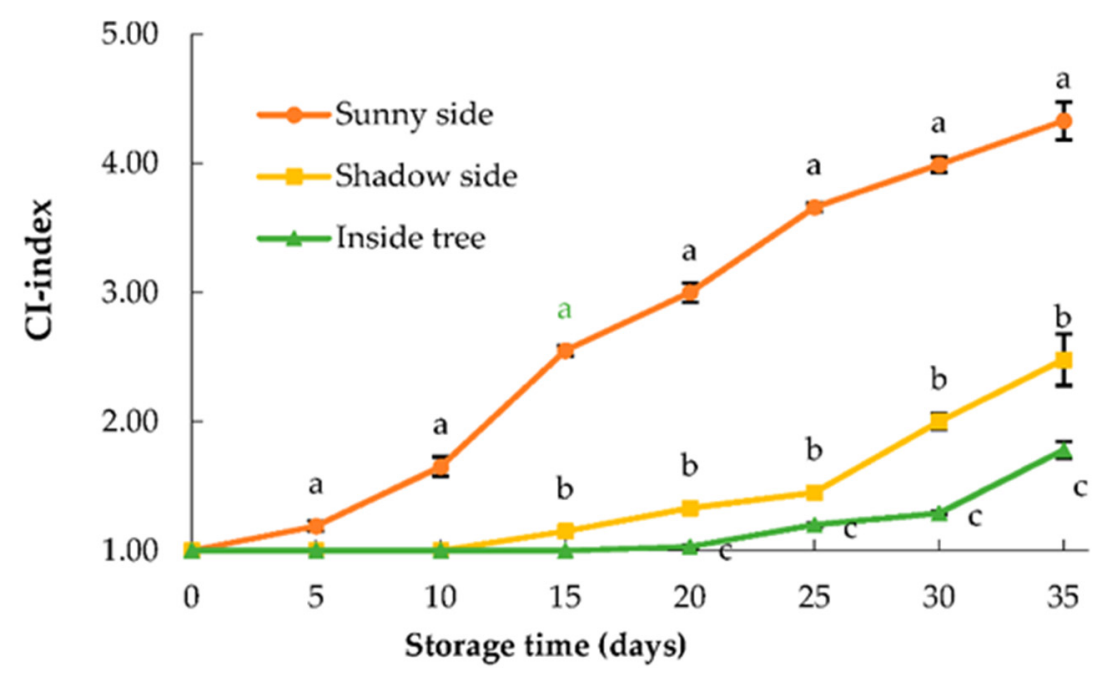

Figure 5. The chilling injury index (CI index) of 'Ewas' mango fruit harvested from different locations (the sunny side of trees, shaded, and inside the trees) and subjected to cold storage at $4{ }^{\circ} \mathrm{C}$. The values represent the mean level of fruit location \pm SE $(n=3)$. Tukey's HSD test $(p<0.05)$ was used for means separation. The letters indicate significant differences between fruit locations.

Although there was an increase in damage during the storage period until the 20th day, the degree of damage that developed between the 10th and the 20th day of storage was slight. CI changed rapidly between the 20th and the 35th day of cold storage. The degree of CI was, in general, less severe for fruit harvested from INS trees on the 35th day (1.66, CI index: less than slight injury) compared to SHA (2.25, CI index, slight injury) and SUN (4.22, CI index, almost very severe injury) trees, see Figure 6.

\subsection{Antioxidant Enzyme Activities}

The changes in the antioxidant enzyme activities (unit $\mathrm{g}^{-1} \mathrm{FW}$ ) as a function of storage time in days for the biological differences of 'Zibda' mango under low temperature were illustrated (Figure 7). Clearly, the antioxidant enzymes exhibited a significant interaction at $p<0.05$ when the storage time and fruit locations were considered. Initially, there were different values for the antioxidant enzyme activities at harvest time overall for the enzymes. The APX enzyme activity increased to reach its maximum on the 20th day. However, the POD, CAT, and SOD enzymes reached their peak on the 15th day of cold storage. Obviously, fruits on the INS side of trees exhibited higher antioxidant activities for all enzymes compared to fruits from the SHA and SUN sides during cold storage at $4{ }^{\circ} \mathrm{C}$. However, fruits picked from the SUN side showed a strong decline in antioxidant enzyme activities after the 20th day until the end of the cold storage period. 
SUN
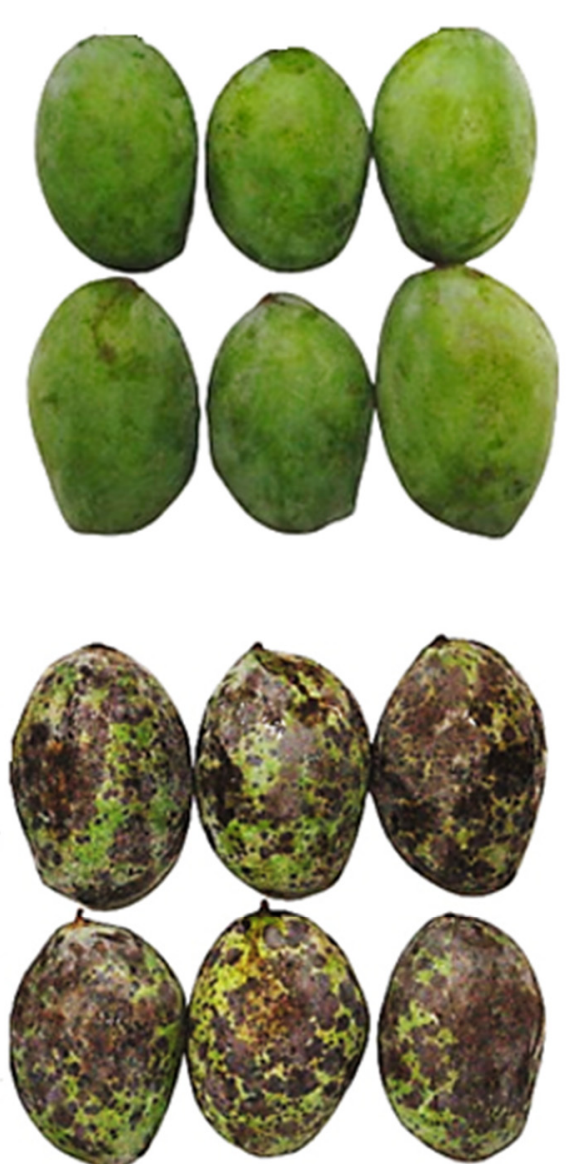

SHA

At harvest time

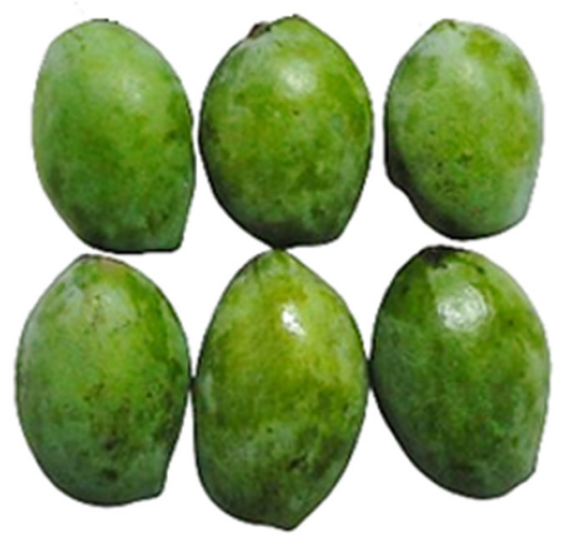

On the $35^{\text {th }}$ day of cold storage

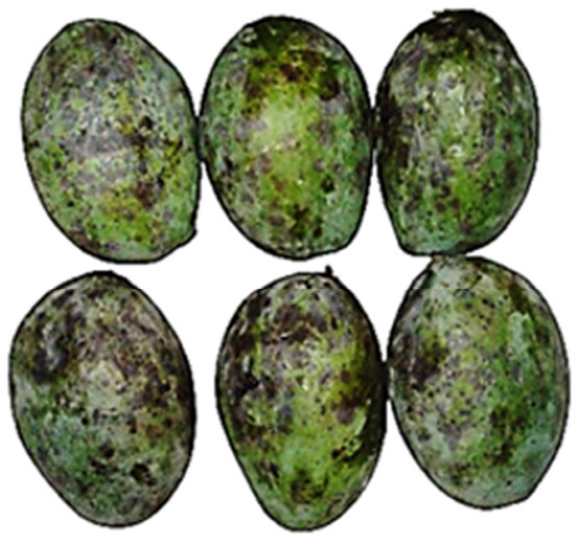

INS
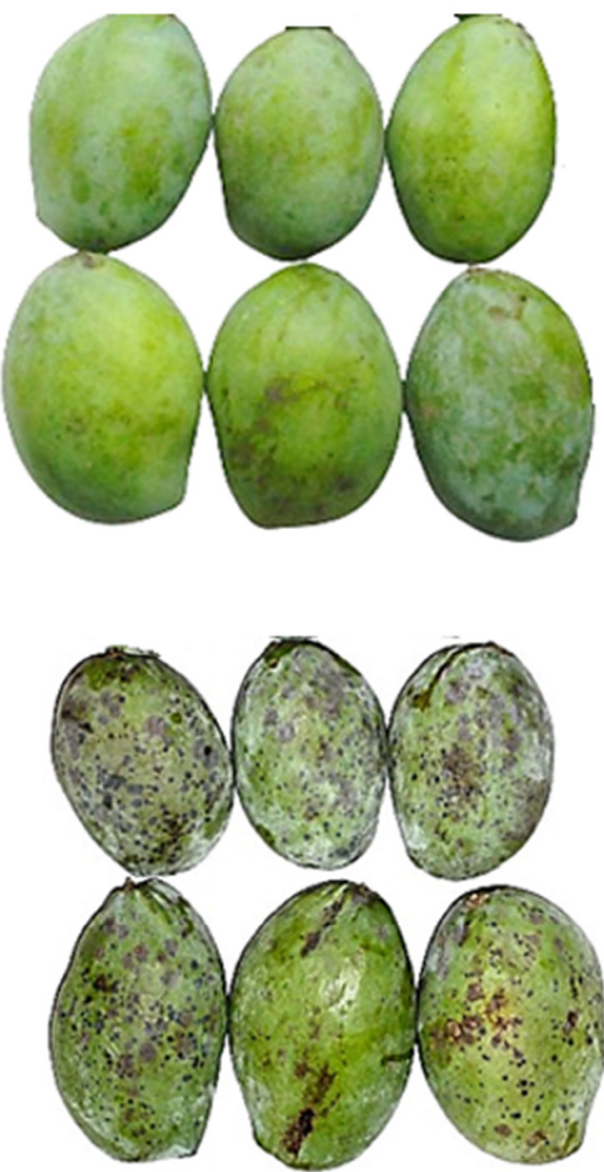

Figure 6. The different responses to low storage temperature due to fruit location on the trees. 


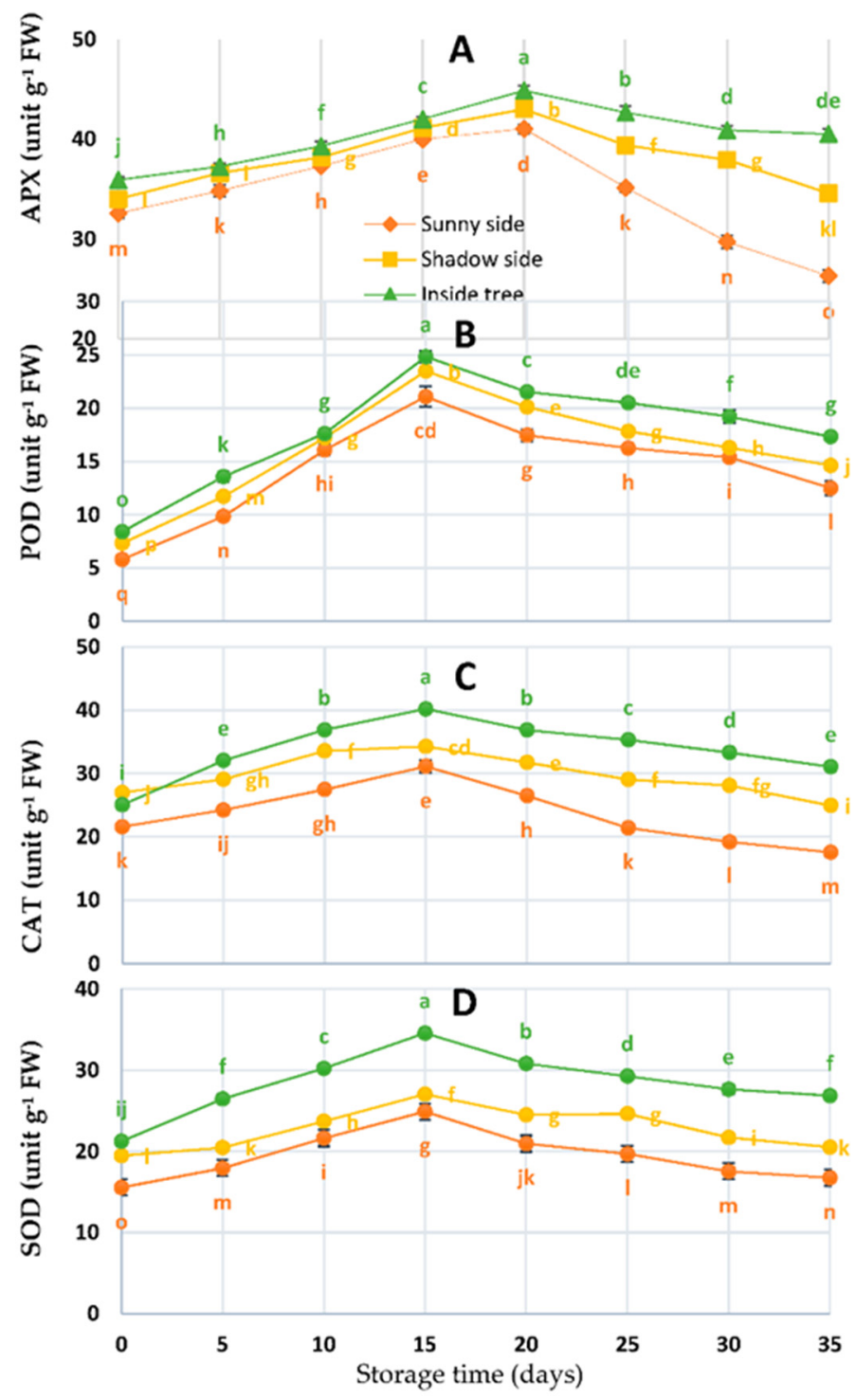

Figure 7. The antioxidant enzyme APX (A), POD (B), CAT (C), SOD (D) activities of 'Ewas' mango fruit harvested from different locations (the sunny side of trees, shaded, and the inside of trees) and subjected to cold storage at $4{ }^{\circ} \mathrm{C}$. The values represent the mean level of fruit location $\pm \mathrm{SE}(\mathrm{n}=3)$. Tukey's HSD test $(p<0.05)$ was used for means separation. The letters indicate significant differences between fruit locations.

\section{3. $M D A, P C G, E L \%$, and Ascorbic Acid}

The variations in lipid peroxidation (MDA), protein oxidation (PCG), cell membrane leakage (IL\%), and ascorbic acid are depicted in Figure 8. The oxidized cell membrane compartment presented a significant interaction at $p<0.05$ when the storage factors such as time and fruit locations were considered.

Initially, the results of MDA, PCG, IL\%, and ascorbic acid were obtained at harvest time and were different overall from the experiments due the fruit locations. Cellar degradation increased gradually until the end of the cold storage period. The fruit harvested from different locations exhibited a significant variation in MDA, PCG, and ascorbic acid content during cold storage. The obvious results were that the INS fruit location had less accumulation of MDA and PCG, as well as lower IL\%. However, fruits from SUN and SHA presented more rapid accumulation and an increase in cell membrane permeability until the end of the cold storage period. Likewise, fruits harvested from the sunny side of trees had a more rapid accumulation of MDA, PCG, and IL\% during 35 days of cold storage. 
The change in lipids and proteins in cell membranes due to cold storage stress terminated MDA and PCG accumulation. Consequently, dysfunction in the cell membrane resulted in increased cell permeability until the end of the experiment. However, the ascorbic acid decreased gradually according to the fruit location. The fruit picked from inside the tree had a higher ascorbic content than other fruit locations.
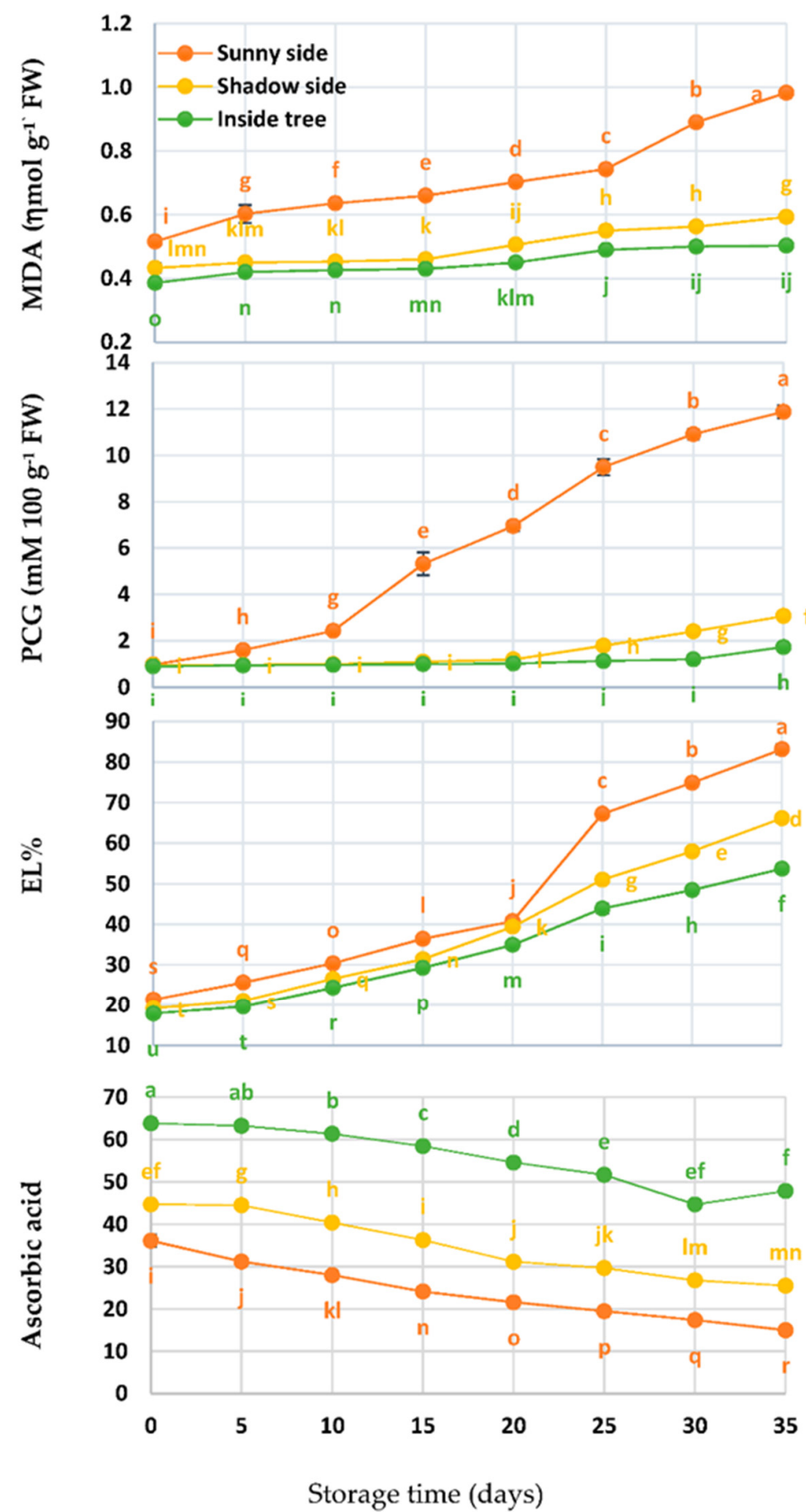

Figure 8. The lipid peroxidation (malondialdehyde, MDA), protein oxidation (protein carbonyl group, PCG), cell membrane leakage percentage, and ascorbic acid content of 'Zibda' mango fruit harvested from different locations (the sunny side of trees, shaded, and the inside of trees) and subjected to cold storage at $4{ }^{\circ} \mathrm{C}$. The values represent the mean level of fruit location $\pm \mathrm{SE}(\mathrm{n}=3)$. Tukey's HSD test $(p<0.05)$ was used for means separation. The letters indicate significant differences between fruit locations. 


\section{4. $\mathrm{O}_{2}{ }^{-} ; \mathrm{H}_{2} \mathrm{O}_{2}$ Production Rates, and DPPH ${ }^{*}$}

The variations between $\mathrm{O}_{2}{ }^{-}, \mathrm{H}_{2} \mathrm{O}_{2}$ production rates, and $\mathrm{DPPH}^{*}$ reduction \% were calculated as a function of the cold storage period in days (Figure 9). There was a significant interaction at $p \leq 0.001$ when cold storage time (days) and fruit locations on trees were considered. Initially, there were different values of $\mathrm{O}_{2}{ }^{-}$and $\mathrm{H}_{2} \mathrm{O}_{2}$ production rates at harvest time between fruit locations. Generally, $\mathrm{O}_{2}{ }^{-}$and $\mathrm{H}_{2} \mathrm{O}_{2}$ production increased gradually during 15 days of cold storage at all fruit locations. Thereafter, both $\mathrm{O}_{2}{ }^{-}$and $\mathrm{H}_{2} \mathrm{O}_{2}$ production increased independently according to fruit location during 35 days of cold storage. However, the $\mathrm{DPPH}^{*}$ reduction decreased gradually across all fruit locations. We observed that the fruit harvested from INS had a lower reduction $(1.18 \%)$ in $\mathrm{DPPH}^{*}$ than other locations (SUN; 0.36 and SHA; $0.85 \%$ ) on the 35th day of cold storage. Fruits harvested from the INS side of trees were the lowest in both $\mathrm{O}_{2}{ }^{-}$and $\mathrm{H}_{2} \mathrm{O}_{2}$ production $\left(0.200 \mathrm{mmol} \mathrm{min}^{-1} \mathrm{~g}^{-1} \mathrm{FW}\right.$ and $\left.0.680 \mathrm{nmol} \mathrm{g}^{-1} \mathrm{FW}\right)$. However, other locations, SUN $\left(0.460 \mathrm{mmol} \mathrm{min}^{-1} \mathrm{~g}^{-1} \mathrm{FW}\right.$ and $\left.1.260 \mathrm{nmol} \mathrm{g}{ }^{-1} \mathrm{FW}\right)$ and SHA $\left(0.290 \mathrm{mmol} \mathrm{min}^{-1} \mathrm{~g}^{-1} \mathrm{FW}\right.$ and $1.060 \mathrm{nmol} \mathrm{g}^{-1} \mathrm{FW}$ ) had much higher values on the 35th day of cold storage.

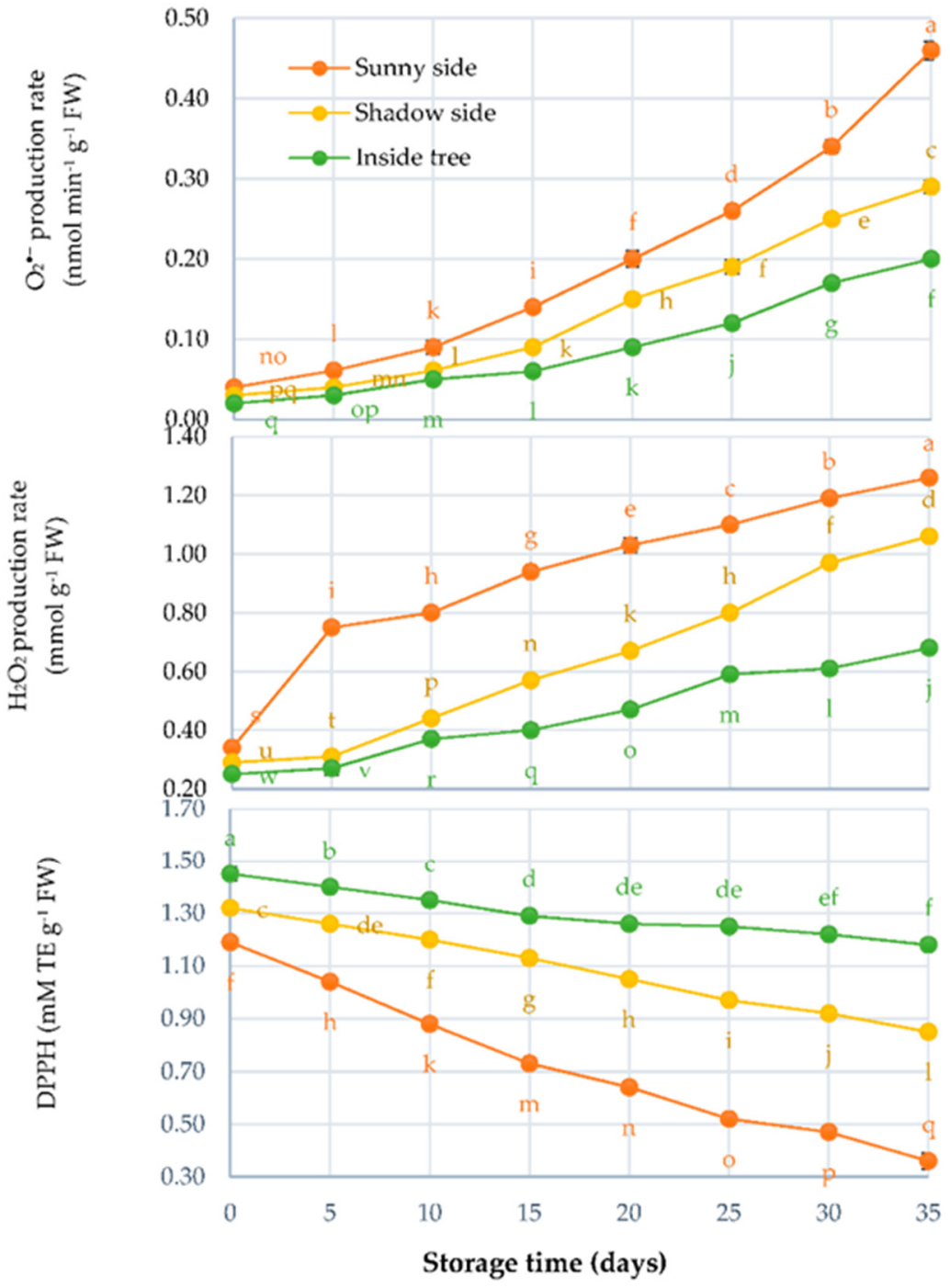

Figure 9. The $\mathrm{O}_{2}{ }^{\bullet-}$ production rate $\left(\mathrm{nmol} \mathrm{min}^{-1} \mathrm{~g}^{-1} \mathrm{FW}\right), \mathrm{H}_{2} \mathrm{O}_{2}$ production rate $\left(\mathrm{mmol} \mathrm{g}^{-1} \mathrm{FW}\right)$, and $\mathrm{DPPH}^{*}$ reduction reaction $\left(\mathrm{mM} \mathrm{TE} \mathrm{g}^{-1} \mathrm{FW}\right)$ of 'Zbida' mango fruit harvested from different locations (the sunny side of trees, shaded, and the inside of trees) and subjected to cold storage at $4{ }^{\circ} \mathrm{C}$. The values represent the mean level for the fruit location \pm SE $(n=3)$. Tukey's HSD test $(p<0.05)$ was used for means separation. The letters indicate significant differences between fruit locations. 


\subsection{Ethelene and Respiration Production}

The differences in ethylene $\left(\mathrm{C}_{2} \mathrm{H}_{4}\right)$ and respiration $\left(\mathrm{CO}_{2}\right)$ in storage time (days) for the 'Zibda' mango are shown (Figure 10). The interaction at $p<0.001$ was significant when storage time in days and fruit locations were considered. Generally, throughout the storage at low temperatures, the $\mathrm{C}_{2} \mathrm{H}_{4}$ emission increased to a maximum that was higher than the initial values (4-6 times) for fruit picked from the sunny side compared to other locations on the 5th day of cold storage. Further, the difference between fruit locations increased on the 5th day independently (Figure 10A). However, respiration was shown as an increase in $\mathrm{CO}_{2}$ reaching a peak on the 10th day of cold storage. Then, $\mathrm{CO}_{2}$ decreased sharply up to the 15th day. After that, it increased steadily until the end of the storage period. Furthermore, the increases in the degree of $\mathrm{CI}$ were independent of fruit maturity (Figure 10B).

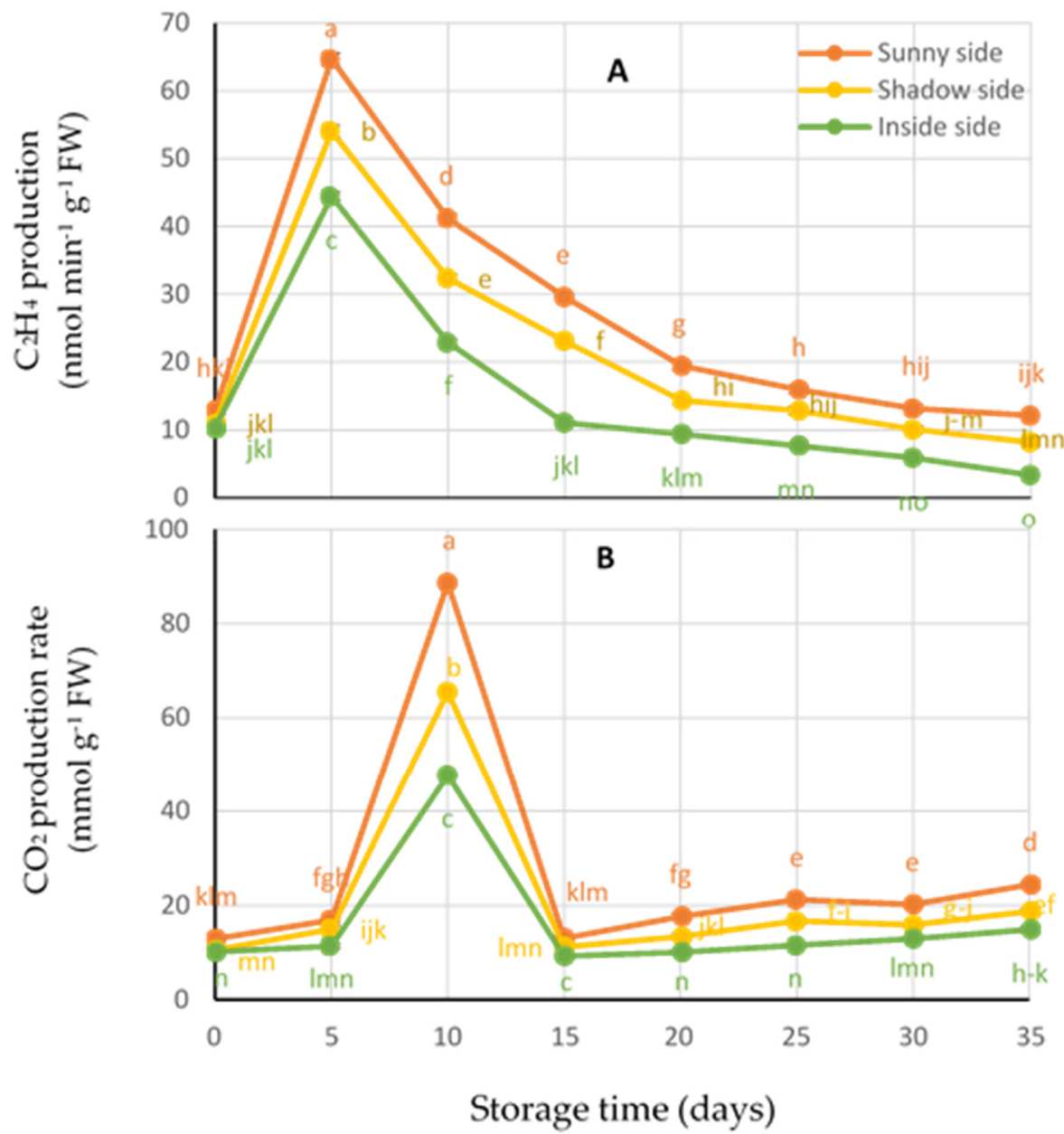

Figure 10. The $\mathrm{C}_{2} \mathrm{H}_{4}(\mathbf{A})$ and $\mathrm{CO}_{2}(\mathbf{B})$ production of 'Zbida' mango fruit harvested from different locations (the sunny side of trees, shaded, and the inside of trees) and subjected to cold storage at $4{ }^{\circ} \mathrm{C}$. The values represent the mean level for the fruit location \pm SE $(n=3)$. Tukey's HSD test $(p<0.05)$ was used for means separation. The letters indicate significant differences between fruit locations.

\subsection{Data Correlations}

PCA for physiological and biochemical parameters obtained from stored fruit was performed for different fruit locations (sunny, shaded, and inside the tree) and storage duration in days (eight levels) for 'Zibda' mango. Pearson's correlations are displayed in Table 1. 
Table 1. Pearson's correlation coefficients among the examined parameters of 'Zibda' mango under cold storage.

\begin{tabular}{|c|c|c|c|c|c|c|c|c|c|c|c|c|c|}
\hline & CI Index & CAT & APX & POD & SOD & MDA & PCG & $\mathrm{C}_{2} \mathrm{H}_{4}$ & $\mathrm{CO}_{2}$ & EL\% & $\mathrm{O}_{2} \cdot-$ & $\mathrm{H}_{2} \mathrm{O}_{2}$ & DPPH $^{*}$ \\
\hline CI Index & * 1.0000 & -0.5837 & -0.5055 & 0.0045 & -0.4578 & 0.9335 & 0.9760 & -0.1403 & 0.0454 & 0.7455 & 0.8132 & 0.8591 & -0.9048 \\
\hline CAT & & 1.0000 & 0.8762 & 0.7312 & 0.9587 & -0.6569 & -0.6216 & -0.0676 & -0.0532 & -0.3995 & -0.4844 & -0.4750 & 0.5245 \\
\hline APX & & & 1.0000 & 0.7137 & 0.8118 & -0.6062 & -0.5816 & -0.1083 & -0.0964 & -0.3611 & -0.4469 & -0.3470 & 0.4091 \\
\hline POD & & & & 1.0000 & 0.7752 & -0.0800 & -0.0430 & -0.2241 & 0.0154 & 0.1769 & 0.0965 & 0.1565 & -0.1157 \\
\hline SOD & & & & & 1.0000 & -0.5620 & -0.4815 & -0.2003 & -0.0710 & -0.2486 & -0.3476 & -0.3943 & 0.4395 \\
\hline MDA & & & & & & 1.0000 & 0.9351 & -0.0482 & 0.1194 & 0.7732 & 0.8432 & 0.8927 & -0.9171 \\
\hline PCG & & & & & & & 1.0000 & -0.1398 & 0.0242 & 0.7569 & 0.8149 & 0.8195 & -0.8829 \\
\hline $\mathrm{C}_{2} \mathrm{H}_{4}$ & & & & & & & & 1.0000 & 0.3164 & -0.4597 & -0.3990 & -0.1712 & 0.0640 \\
\hline $\mathrm{CO}_{2}$ & & & & & & & & & 1.0000 & -0.0778 & -0.0558 & 0.0736 & -0.1278 \\
\hline EL\% & & & & & & & & & & 1.0000 & 0.9763 & 0.8715 & -0.7805 \\
\hline $\mathrm{O}_{2} \cdot-$ & & & & & & & & & & & 1.0000 & 0.8968 & -0.8247 \\
\hline $\mathrm{H}_{2} \mathrm{O}_{2}$ & & & & & & & & & & & & 1.0000 & -0.9351 \\
\hline $\mathrm{DPPH}^{*}$ & & & & & & & & & & & & & 1.0000 \\
\hline
\end{tabular}

* Data are average values of fruit locations and storage time. CI Index-Chilling injury index; CAT-Catalase; APX-Ascorbate peroxidase; POD—Peroxidase; SOD—Superoxide dismutase; MDA—Malondialdehyde accumulation; PCG— Protein carbonyl group; $\mathrm{C}_{2} \mathrm{H}_{4}-\mathrm{Ethylene}$ production; $\mathrm{CO}_{2}$-Respiration; $\mathrm{EL} \%$-Electrolyte leakage percentage; $\mathrm{O}_{2}$-Superoxide radical; $\mathrm{H}_{2} \mathrm{O}_{2}-\mathrm{Hydrogen}_{\text {peroxide; }} \mathrm{DPPH} \mathrm{H}^{*}-$ Radical scavenging.

\section{Discussion}

Sunny fruits were more sensitive to cold temperatures due to enhanced physiological changes in cell membrane compartments under cold stress, which is not reversible [32]. The increases in the degree of $\mathrm{CI}$ were independent of the fruit maturity stage. This would appear to be an important biological factor when cold storage is required for mango fruit [15]. Accordingly, the visual appearance of CI symptoms on 'Zibda' mango fruit changed according to the effect of three different biological factors. It seems that the change in CI could be related to exposure to solar heat and radiation stress during fruit development. Fruits located on the SUN side displayed more CI symptoms compared to fruits from other locations. The difference in CI symptoms among fruit locations could be explained by the fact that fruit from INS had higher antioxidant activities than ROS generation compared to SHA and SUN during cold storage [33]. These increases provide fruit with more resistance to chilling damage $[10,34]$. Fruits are exposed to high temperatures during the growing season, which leads to the activation of antioxidants during storage [35]. However, prolonged exposure may lead to the reduction of vitamin $C$ levels and thus reduce the action of antioxidant enzymes during cold storage [36]. However, the fruit harvested from different locations could have a different content of antioxidants and ROS production $[37,38]$ as a consequence of the relationship between the formation and scavenging of ROS, also known as homeostasis [33].

From the results of the experiments, fruit location has a significant impact on the activity of antioxidants during the cold storage period. Thus, it can be argued that increasing the activity of antioxidants until the 15th day protects fruit against free radicals generated by low-temperature storage stress. This could be reflected in the protection of cell walls from oxidation reactions and hence the absence of symptoms of injury on fruits. This was clear, especially for the fruit from INS trees. Further, it suggested that the INS fruits had higher antioxidant activities for quenching ROS during long-term cold storage. The INS fruit presented fewer CI symptoms compared to other fruit locations [37]. Therefore, more CI symptoms appeared on fruits that were harvested from SUN location on trees due to the decrease in antioxidant activities.

Chilling injury symptoms because of exposure of fruit to low temperature have often been associated with oxidative stress processes [39,40]. Consequently, the oxidative stress reaction occurs as a result of the imbalance between the production of ROS and antioxidant levels [41]. Further, the accumulation of MDA and protein carbonyl is due to the impact of ROS or oxidative reaction processes on stressed tissue [15,42]. Thus, it would be expected that the fruit on the SUN side of the tree might be stressed before harvesting (heat and rays of the sun). Hence, it could be more sensitive to low-temperature storage, with greater CI symptom incidence [37]. The growth of mango fruits under the sun and prolonged 
exposure before harvesting may lead to increased activity of decomposing enzymes such as cellulose and polygalacturonase [8], thus increasing fruit softening before storage [43]. However, the accumulation of MDA and PCG appears to be largely independent of fruit locations. Fruits harvested from INS had the fewest CI symptoms compared to the SHA and SUN locations. The fruit located in INS may have had a better balance between ROS and quenching antioxidants [33,44].

The highest amount of $\mathrm{O}_{2}{ }^{-}$and $\mathrm{H}_{2} \mathrm{O}_{2}$ production in the experiment could be due to other physiological processes such as respiration [45]. Therefore, the increase in antioxidant enzyme activities such as APX, POD, CAT, and SOD could also enhance fruit tissue defense against $\mathrm{O}_{2}{ }^{-}$generation by quenching them during the storage period under low-temperature stress. Consequently, increasing antioxidant activities would participate strongly in scavenging $\mathrm{O}_{2}{ }^{-}$and $\mathrm{H}_{2} \mathrm{O}_{2}$ production during cold stress [29]. These results explain why fruit on the INS side of trees was more tolerant of cold temperatures. Further, the fruit had higher antioxidant enzyme activities, which provides protection against chilling damage. Moreover, the increased antioxidants scavenged $\mathrm{O}_{2}{ }^{-}$and $\mathrm{H}_{2} \mathrm{O}_{2}$ generation during cold stress $[33,46]$.

Mangoes are frequently collected at the green mature stage for export because they are climacteric fruits. When the mature stage of the fruit is not managed at harvest, batches of both unripe and overripe fruit arrive on the market. Consumers purchase mangoes with very different sensory qualities (i.e., sweetness, firmness, pulp color, and aroma) that do not satisfy their expectations [47]. The varieties, storage length, temperature, and fruit development stage all have an impact on $\mathrm{C}_{2} \mathrm{H}_{5}$ and $\mathrm{CO}_{2}$ production. This could be because the fruit peel contains more ethylene, more ACC oxidase (ACO), and less 1-aminocyclopropane-1carboxylic acid (ACC) than the outer and inner mesocarps at the mature-green stage [48]. The action of $\mathrm{C}_{2} \mathrm{H}_{5}$ on fruit is associated with changes in climacteric respiration and membrane characteristics, including phospholipid loss and increased membrane permeability. The ethylene concentration in fruits is less than the minimum level required to commence ripening and provide protection against the development of CI symptoms. Additionally, earlier research has demonstrated that the respiration-related indirect effect on lipid cell membrane peroxidation occurs through the generation of reactive oxygen species (ROS) throughout the respiration process, producing oxidative stress. It might also be defined by an increase in MDA, which means enhanced cell injury [15]. Temperature and gas composition are reported to suppress the respiration rate, while the mechanism by which mango's respiratory rate is slowed by decreasing the oxygen $\left(\mathrm{O}_{2}\right)$ level is unknown [49]. This is attributable to the rapid disruption of carbohydrates and organic molecules at high temperatures caused by a variety of chemicals and enzyme activity [50].

Exposure to light and temperature during the production stage accelerated the ripening of bananas, which was marked by a reduced pre-climacteric period [51]. Exposure of 'Hass' avocado fruit to the sun can result in fruit temperatures as high as $43{ }^{\circ} \mathrm{C}$. The exposed fruit (sun fruit) has a higher tolerance to postharvest heat and cold treatments than shade fruit [52]. Our findings conflict with the previous reports. We found that the fruit in the SUN location had greater sensitivity to low temperatures than other fruits. Because temperature stress is caused by direct sunlight, it is possible that some of the stress is a response to ultraviolet (UV) wavelengths rather than the heat response caused by infrared wavelengths. We believe that the UV response, if it exists, is minor for three reasons [53].

\section{Conclusions}

In conclusion, the difference in the locations of 'Zibda' mango fruit on the trees (sunny and shaded sides and inside the trees) affected the fruit behavior during cold storage, as well as the activity of antioxidant enzymes and, consequently, CI symptoms. Fruits harvested from INS had lower sensitivity to low-temperature storage and fewer CI symptoms due to higher antioxidant enzyme activity. Moreover, fruits that were located inside trees had less exposure to heat and UV stress, which improved the tolerance to low 
temperatures. We suggest that the location of mango fruits on trees should be taken into consideration during the harvest process.

Author Contributions: Data curation, A.A.L.; Formal analysis, A.A.L.; Funding acquisition, N.A.M., N.A.A.-H., S.H. and M.A.A.; Investigation, N.A.A.-H.; Methodology, M.A.A.; Project administration, S.M.A.-Q.; Resources, S.M.A.-Q.; Software, A.A.L. All authors have read and agreed to the published version of the manuscript.

Funding: This research was funded by the Taif University Researchers Supporting Project (TURSP2020/142), Taif University, Taif, Saudi Arabia.

Institutional Review Board Statement: Not applicable.

Informed Consent Statement: Not applicable.

Data Availability Statement: Relevant data applicable to this research are within the paper.

Conflicts of Interest: The authors declare no conflict of interest.

\section{References}

1. Yasunaga, E.; Fukida, S.; Nagle, M.; Spreer, W. Effect of storage conditions on the postharvest quality changes of fresh mango fruits for export during transportation. Environ. Control Biol. 2018, 56, 39-44. [CrossRef]

2. Sivakumar, D.; Jiang, Y.; Yahia, E.M. Maintaining mango (Mangifera indica L.) fruit quality during the export chain. Food Res. Int. 2011, 44, 1254-1263. [CrossRef]

3. FROSTAT. 2019. Available online: http:/ / www.fao.org/faostat/ (accessed on 21 July 2021).

4. Barman, K.; Asery, R. Salicylic acid pre-treatment alleviates chilling injury, preserves bioactive compounds and enhances shelf life of mango fruit during cold storage. J. Sci. Ind. Res. 2014, 73, 713-718.

5. Moretti, C.L.; Mattos, L.M.; Calbo, A.G.; Sargent, S.A. Climate changes and potential impacts on postharvest quality of fruit and vegetable crops: A review. Food Res. Int. 2010, 43, 1824-1832. [CrossRef]

6. Henson, R. The Rough Guide to Climate Change, 2nd ed.; Penguim Books: London, UK, 2008; p. 384.

7. Kays, S.J. Postharvest Physiology of Perishable Plant Products; AVI: Athens, Greece, 1997; 532p.

8. Woolf, A.B.; Ferguson, I.B.; Requejo-Tapia, L.C.; Boyd, L.; Laing, W.A.; White, A. Impact of sun exposure on harvest quality of 'Hass' avocado fruit. Rev. Chapingo Ser. Hortic 1999, 5, 352-358.

9. Ferguson, I.B.; Lurie, S.; Bowen, J.H. Protein synthesis and breakdown during heat shock of cultured pear (Pyrus communis L.) cells. Plant Physiol. 1994, 104, 1429-1437. [CrossRef]

10. Nair, S.; Singh, Z. Pre-storage ethrel dip reduces chilling injury, enhances respiration rate, ethylene production and improves fruit quality of 'Kensington Pride' mango. J. Food Agric. Environ. 2003, 1, 93-97.

11. Shewfelt, R.L.; Del Rosario, B.A. The role of lipid peroxidation in storage disorders of fresh fruits and vegetables. Hortscience 2000, 35, 575-579. [CrossRef]

12. Nair, S.; Singh, Z. Chilling injury during storage affects respiration rate and fruit quality in 'Kensington Pride' mango fruit. Acta Hortic. 2009, 820, 737-743. [CrossRef]

13. Mittler, R. Oxidative stress, antioxidants and stress tolerance. Trends Plant Sci 2002, 7, 405-410. [CrossRef]

14. Junmatonga, C.; Faiyueb, B.; Rotarayanonta, S.; Uthaibutraa, J.; Boonyakiatc, D.; Saengnila, K. Cold storage in salicylic acid increases enzymatic and non-enzymatic antioxidants of Nam Dok Mai No. 4 mango fruit. Sci. Asia 2015, 41, 12-21. [CrossRef]

15. Lo'ay, A.A. Chilling Injury in Mangoes. Ph.D. Thesis, Wageningen University, Wageningen, NL, USA, $2005 ;$ pp. 1-224.

16. Lo'ay, A.A.; Dawood, H.D. Tolerance of 'Baladi' mandarin fruits to cold storage by postharvest pectin/PVA blend with ascorbic acid treatment. Sci. Hortic. 2019, 256, 108637. [CrossRef]

17. Peiyan, L.; Xiaolin, Z.; Golam Ferdous, C.M.; Kim, C.; Jeffrey, K.B. Prestorage Application of Oxalic Acid to Alleviate Chilling Injury in Mango Fruit. HortSci. Horts 2015, 50, 1795-1800. [CrossRef]

18. Wang, C.Y. Reducing chilling injury and maintaining quality of horticultural crops with natural products and their derivatives. Acta Hortic. 2006, 712, 285-290. [CrossRef]

19. Rodeo, A.J.D.; Esguerra, E.B. Low temperature conditioning alleviates chilling injury in mango (Mangifera indica L. cv. Carabao) fruit. Philipp. J. Crop Ssi. 2013, 38, 24-32.

20. Pristijono, P.; Golding, J.B.; Bowyer, M.C. Postharvest UV-C Treatment, Followed by Storage in a Continuous Low-Level Ethylene Atmosphere, Maintains the Quality of 'Kensington Pride' Mango Fruit Stored at $20{ }^{\circ} \mathrm{C}$. Horticulturae 2019, 5, 1. [CrossRef]

21. Majeed, M.; Jeffery, K.B. Reduction of chilling injury in 'Tommy Atkins' mangoes during ripening. Sci. Hortic. 2002, 95, 297-308.

22. Chaplin, G.R.; Cole, S.R.; Landrin, M.; Nuevo, P.A.; Lam, P.F.; Graham, G. Chilling injury and storage of mango (Mangifera indica L.) held under low temperatures. Acta Hortic. 1991, 291, 461-471. [CrossRef]

23. Hakim, A.; Purvis, A.C.; Mullinix, B.G. Differences in chilling sensitivity of cucumber varieties depends on storage temperature and the physiological dysfunction evaluated. Postharvest Biol. Technol. 1999, 17, 97-104. [CrossRef] 
24. Wang, Y.S.; Tian, S.P.; Xu, Y. Effects of high oxygen concentration on pro- and antioxidant enzymes in peach fruit during postharvest periods. Food Chem. 2005, 91, 99-104. [CrossRef]

25. Zhang, X.; Shen, L.; Li, F.; Meng, D.; Sheng, J. Arginase induction by heat treatment contributes to amelioration of chilling injury and activation of antioxidant tenzymes in tomato fruit. Postharvest Biol. Technol. 2013, 79, 1-8. [CrossRef]

26. Tian, S.P.; Li, B.Q.; $\mathrm{Xu}, \mathrm{Y}$. Effects of $\mathrm{O}_{2}$ and $\mathrm{CO}_{2}$ concentration on physiology and quality of litchi fruit in storage. Food Chem. 2005, 91, 659-663. [CrossRef]

27. Iturbe-Ormaetxe, I.; Escuredo, P.R.; Arrese-Igor, C.; Becana, M. Oxidative damage in pea plants exposed to water deficit or paraquat. Plant Physiol. 1998, 116, 173-181. [CrossRef]

28. Levine, R.L.; Williams, J.A.; Stadtman, E.R.; Schacter, E. Carbonyl assay for determination of oxidatively modified proteins. Methods Enzym. 1994, 233, 346-357.

29. Yang, H.; Wu, F.; Cheng, J. Reduced chilling injury in cucumber by nitric oxide and the antioxidant response. Food Chem. 2011, 127, 1237-1242. [CrossRef]

30. Xu, M.; Dong, J.; Zhang, M.; Xu, X.; Sun, L. Cold-induced endogenous nitric oxide generation plays a role in chilling tolerance of loquat fruit during postharvest storage. Postharvest Biol. Technol. 2012, 65, 5-12. [CrossRef]

31. Yen, G.C.; Chen, H.Y. Antioxidant activity of various tea extracts in relation to their antimutagenicity. J. Agric. Food Chem. 1995, 43, 27-32. [CrossRef]

32. Leshem, Y.Y. Plant Membranes: A Biophysical Approach to Structure, Development and Senescence; Kluwer Acadamic Publishers: Dordrecht, The Netherlands, 1992; pp. 1-266, ISBN 0792313534.

33. Foyer, C.H.; Ruban, A.V.; Noctor, G. Viewing oxidative stress through the lens of oxidative signaling rather than damage. Biochem. J. 2017, 474, 877-883. [CrossRef]

34. Lo'ay, A.A.; Dawood, H.D. Chilling injury, fruit color maturity stages, and antioxidant enzyme activities of lemon 'baladi CV' fruits under cold storage stress. Sci. Hortic. 2019, 257, 108676. [CrossRef]

35. Galletta, G.J.; Bringhurst, R.S. Strawberry management. In Small Fruit Crop Management; Galletta, G.J., Bringhurst, R.S., Eds.; Prentice-Hall: Englewood Cliffs, NJ, USA, 1990; pp. 83-156.

36. McKeon, A.W.; Warland, J.; McDonald, M.R. Long-term climate and weather patterns in reation to crop yield: A minireview. Can. J. Bot. 2006, 84, 1031-1036. [CrossRef]

37. Usha, K.; Thakre, M.; Goswami, A.K.; Nayan, D.G. Fundamental of Fruit Production; Division of Fruits and Horticultural Technology; Indian Agricultural Research Institute: New Delhi, Indian, 2015; pp. 1-245.

38. Lo'ay, A.A.; Doaa, M.H. The potential of vine rootstocks impacts on 'Flame Seedless' bunches behavior under cold storage and antioxidant enzyme activity performance. Sci. Hortic. 2020, 260, 108844. [CrossRef]

39. Hodges, D.M. Overview: Oxidative stress and postharvest produce. In Postharvesst Oxidative Stress in Horticultural Crops; Hodges, D.M., Ed.; Food Products Press: New York, NY, USA, 2003; pp. 1-12.

40. Lo'ay, A.A.; El-Khateeb, A.Y. Antioxidant enzyme activities and exogenous ascorbic acid treatment of 'Williams' banana during long-term cold storage stress. Sci. Hortic. 2018, 234, 210-219. [CrossRef]

41. Hodges, D.M.; Lester, G.E.; Munro, K.D.; Toivonen, P.M.A. Oxidative stress: Importance for postharvest quality. HortScience 2004, 39, 924-929. [CrossRef]

42. Lo'ay, A.A.; Taher, M.A. Effectiveness salicylic acid blending in chitosan/PVP biopolymer coating on antioxidant enzyme activities under low storage temperature stress of 'Banati' guava fruit. Sci. Hortic. 2018, 238, 343-349. [CrossRef]

43. Hicks, J.R.; Manzano-Mendez, J.; Masters, J.F. Temperature extremes and tomato ripening. In Proceedings of the Fourth Tomato Quality Workshop, Miami, FL, USA, 7-10 March 1983.

44. Foyer, C.H.; Noctor, G. Redox sensing and signalling associated with reactive oxygen in chloroplasts, peroxisomes and mitochondria. Physiol. Plant 2003, 119, 355-364. [CrossRef]

45. Tang, T.; Huang, D.-W.; Zhou, C.-Q.; Li, X.; Xie, Q.-J.; Liu, F.-S. Molecular cloning and expression patterns of copper/zinc superoxide dismutase and manganese superoxide dismutase in Musca domestica. Gene 2012, 505, 211-220. [CrossRef] [PubMed]

46. Lo'ay, A.A.; Taha, N.A.; El-Khateeb, Y.A. Storability of 'Thompson Seedless' grapes: Using biopolymer coating chitosan and polyvinyl alcohol blending with salicylic acid and antioxidant enzymes activities during cold storage. Sci. Hortic. 2019, 249, 314-321. [CrossRef]

47. Zúñiga-Arias, G.; Ruben, R.; van Boekel, M. Managing quality heterogeneity in the mango supply chain: Evidence from Costa Rica. Trends Food Sci. Technol. 2009, 20, 168-179. [CrossRef]

48. Sudhakar Rao, D.V.; Gopalakrishna Rao, K.P. Controlled atmosphere storage of mango cultivars 'Alphonso' and 'Banganapalli' to extend storage-life and maintain quality. J. Hortic. Sci. Biotechnol. 2008, 83, 351-359. [CrossRef]

49. Nakamura, N.; Rao, D.V.S.; Shiina, T.; Nawa, Y. Respiration Properties of Tree-Ripe Mango under CA Condition. Jpn. Agric. Res. Q. JARQ 2004, 38, 221-226. [CrossRef]

50. Singh, Z.; Singh, R.K.; Sane, V.A.; Nath, P. Mango-Postharvest Biology and Biotechnology. Crit. Rev. Plant Sci. 2013, 32, 217-236. [CrossRef]

51. Montefiori, M.; Costa, G.; McGhie, T.; Ferguson, A.R. Effects of light and temperature on colour changes in ripening fruit of actinidia macrosperma. Acta Hortic. 2005, 682, 185-190. [CrossRef] 
52. Woolf, A.B.; Wexler, A.; Prusky, D.; Kobiler, E.; Lurie, S. Direct Sunlight Influences Postharvest Temperature Responses and Ripening of Five Avocado Cultivars. J. Am. Soc. Hortic. Sci. 2000, 125, 370-376. [CrossRef]

53. Prusky, D.; Keen, W.T. Inducible preformed compounds andtheir involvement in the resistance of plant pathogens. In Novel Approaches to Integrated Pest Management; Reuveni, R., Ed.; Lewis Publ. Inc.: Chelsa, MI, USA, 1993; pp. $139-152$. 